\title{
Comparison of the effects of filtration leucapheresis and discontinuous flow centrifugation leucapheresis on granulocyte microbicidal function
}

\author{
S MARTIN, ATM GHONEIM, EAE ROBINSON, JA CHILD
}

From the Department of Microbiology, University of Leeds, National Blood Transfusion Service, Regional Transfusion Centre, Leeds, and the Department of Haematology, Leeds General Infurmary, Great George St, Leeds

SUMMARY In an investigation of the in vitro phagocytic and microbicidal function of granulocytes $i$ collected by filtration leucapheresis (FL) from 18 donors and by discontinuous flow centrifuga- ${ }^{\infty}$ tion leucapheresis (DFC) from six donors, comparison was made with the function of granulo- $\frac{\text { ? }}{5}$ cytes obtained from the same donors by venepuncture and density gradient centrifugation over Ficoll-Isopaque (FI).

No significant impairment of the phagocytosis or killing of Candida guilliermondii by either FL- or DFC-granulocytes was observed. Although the ability of FL-granulocytes to phagocytose $\emptyset_{\infty}$ and kill Staphylococcus aureus did not differ significantly from the function of control FIgranulocytes, DFC-granulocytes were significantly less active.

The three most widely used methods of granulocyte collection for transfusion are filtration leucapheresis (FL), continuous flow centrifugation (CFC) and discontinuous flow centrifugation (DFC). FL provides good yields of granulocytes but morphology and functional integrity have variously been reported as abnormal by some, ${ }^{1-4}$ normal by others. ${ }^{56}$ These discrepancies may reflect differences in collection techniques; in particular the time for which the granulocytes are in contact with the filter ${ }^{2589}$ and the degree of tapping of the filters during elution. ${ }^{4}$ CFC and DFC supply a lower yield of granulocytes but their morphology and function have generally been reported as normal. ${ }^{2-5}$ However, Beaud et al ${ }^{10}$ demonstrated some impairment of DFCgranulocyte function related to the occurrence of degranulation during centrifugation.

For granulocytes to be optimally effective clinically it is important that they should maintain their functional integrity. The apparent differences in functional capacity of granulocytes harvested in different laboratories prompted us to investigate and compare the function of granulocytes harvested by FL and DFC.

\section{Material and methods}

\section{LEUCAPHERESIS DONORS}

Peripheral blood was donated by 24 healthy adults under $50 \mathrm{yr}$ of age. Oral dexamethasone $(8 \mathrm{mg})$ was administered $16 \mathrm{~h}$ before the donation.

\section{COLLECTION OF GRANULOCYTES}

Ficoll-Isopaque separated (FI) granulocytes In order to study the effect of leucapheresis on granulocyte function, FI-granulocytes were used as a control. O Before leucapheresis $10-20 \mathrm{ml}$ heparinised blood was obtained from the donor, layered over Dextran-Isopaque and the red cells sedimented for $D$ $60 \mathrm{~min}$ at $37^{\circ} \mathrm{C} .^{11}$ Granulocytes were then separated from the leucocyte-plasma by centrifugation over $\mathrm{N}$ Ficoll-Isopaque, SG 1.077, at $400 \mathrm{~g}$ for $25 \mathrm{~min} .{ }^{11}$ After washing in Hanks' balanced salt solution $\stackrel{N}{N}$ (HBSS) the granulocytes were resuspended at $5 \times \mathrm{\omega}$ $10 \% \mathrm{ml}$.

FL-granulocytes were harvested using the Fenwale Leukopak system. Donors received 2000-2500 U® heparin intravenously at the beginning of the procedure. Filters were primed with up to $1000 \mathrm{ml}$ normal saline containing $1 \mathrm{U} / \mathrm{ml}$ heparin. Blood flow rate $\frac{O}{\Phi}$ through the filters was $60-65 \mathrm{ml} / \mathrm{min}$ and elution $\stackrel{\rho}{\square}$ was begun not later than $2 \mathrm{~h}$ after commencement. $\stackrel{1}{2}$ Red cells were returned to the donor by rinsing the 
filters with $500 \mathrm{ml}$ normal saline containing $3 \mathrm{U} / \mathrm{ml}$ heparin and the granulocytes then eluted into $4 \times$ $600 \mathrm{ml}$ blood bags with $2000 \mathrm{ml}$ fluid comprising $1570 \mathrm{ml}$ normal saline, $400 \mathrm{ml}$ fresh frozen plasma (FFP) and $30 \mathrm{ml} \mathrm{ACD-A.} \mathrm{Granulocytes} \mathrm{were} \mathrm{con-}$ centrated by centrifugation $\left(400 \mathrm{~g}, 15 \mathrm{~min}\right.$ at $\left.4^{\circ} \mathrm{C}\right)$, pooled and resuspended to $200 \mathrm{ml}$ in FFP. An aliquot from this suspension was washed in HBSS and resuspended to $5 \times 10^{6}$ granulocytes $/ \mathrm{ml}$ for function studies.

DFC-granulocytes were harvested using a Haemonetics Model 30 cell separator with a $225 \mathrm{ml}$ collection bowl. The separator was set up in a standard manner with $500 \mathrm{ml} 6 \%$ hydroxyethyl starch (HES) $+30 \mathrm{ml}$ sodium citrate anticoagulant concentrate, containing $17 \mathrm{~g}$ sodium citrate dihydrate and $800 \mathrm{mg}$ citric acid monohydrate, replacing the usual ACD anticoagulant. When this HES was finished it was then replaced with ACD formula B. The initial flow rate was $60-70 \mathrm{ml} / \mathrm{min}$, being reduced to $20 \mathrm{ml} / \mathrm{min}$ just prior to and during cell collection. Six to eight cycles were performed, yielding $70 \mathrm{ml}$ buffy coat/cycle to give $420-560 \mathrm{ml}$ granulocyte concentrate. An aliquot from this suspension was washed in HBSS and the granulocytes resuspended to $5 \times 10 \% \mathrm{ml}$ for function studies.

GRANULOCYTE FUNCTION STUDIES

All function studies were carried out within 1-2 h of completing the collection procedure.

Phagocytosis of candida

The technique of Yamamura $\mathrm{et} \mathrm{al}^{12}$ was adapted for use with Candida guilliermondii whereby the uptake of ${ }^{3} \mathrm{H}$-uridine by non-ingested candida was used as a measure of phagocytosis. Triplicate assays $\left(5 \times 10^{5}\right.$ granulocytes $+5 \times 10^{6} C$ guilliermondii in $0.5 \mathrm{ml}$ HBSS $+10 \% \mathrm{AB}$ serum) were incubated for $30 \mathrm{~min}$ at $37^{\circ} \mathrm{C}$ and phagocytosis then terminated by the addition of $1 \mathrm{mg}$ phenylbutazone. ${ }^{13}$ Duplicate $0 \cdot 1 \mathrm{ml}$ aliquots were removed and the non-ingested candida quantified by labelling with $5-{ }^{3} \mathrm{H}$-uridine $(0 \cdot 5$ $\mu \mathrm{Ci}, 5 \mathrm{Ci} / \mathrm{mmol}: 30 \mathrm{~min}, 37^{\circ} \mathrm{C}$ ). Candida-associated radioactivity was harvested on to $\mathrm{GF} / \mathrm{C}$ glass fibre filters for liquid scintillation counting.

Killing of candida was assessed by the release of ${ }^{51}$ chromium from labelled $C$ guilliermondii. ${ }^{14}$ Triplicate assays $\left(5 \times 10^{5}\right.$ granulocytes $+1.5 \times 10^{6}{ }^{51} \mathrm{Cr}-C$ guilliermondii in $0.5 \mathrm{ml}$ HBSS $+10 \% \mathrm{AB}$ serum) were incubated for $60 \mathrm{~min}$ at $37^{\circ} \mathrm{C}$. Granulocyte activity was terminated and the granulocytes disrupted by the addition of $2.4 \mathrm{mg}$ sodium deoxycholate and $0.02 \mathrm{mg}$ DNase in $0.2 \mathrm{ml}$; supernatants were taken for gamma counting. Results were expressed as:

$\% \mathrm{Cr}$ release $=\frac{\mathrm{X}-\mathrm{S}}{\mathrm{T}-\mathrm{S}} \times 100$

where $\mathrm{T}=$ total radioactivity in $0.2 \mathrm{ml}$ assay.

$$
\begin{aligned}
& \mathrm{S}=\begin{array}{l}
\text { spontaneous release of chromium from } \\
\text { candida in absence of granulocytes }
\end{array} \\
& \mathrm{X}=\begin{array}{l}
\text { granulocyte-induced release of } \\
\text { chromium }
\end{array}
\end{aligned}
$$

The $\%$ release gave a measure of the $\%$ candida killed. ${ }^{14}$

\section{Phagocytosis of bacteria}

Granulocytes $\left(5 \times 10^{5}\right)$ and methyl- ${ }^{3} \mathrm{H}$-thymidine labelled Staphylococcus aureus $\left(5 \times 10^{6}\right)$ in $0.5 \mathrm{ml}$ HBSS $+10 \%$ AB serum were incubated for $20 \mathrm{~min}$ at $37^{\circ} \mathrm{C} .{ }^{15}$ Phenylbutazone $(1 \mathrm{mg})$ was added to inhibit further phagocytosis ${ }^{13}$ whilst non-ingested bacteria were removed with lysostaphin $(5 \mu \mathrm{g})$. Granulocyte-associated radioactivity was then harvested on to $\mathrm{GF} / \mathrm{C}$ glass fibre filters for liquid scintillation counting. When compared with the total counts-per-min (cpm) in the assay, granulocyteassociated $\mathrm{cpm}$ gave a measure of the degree of phagocytosis.

$\%$ phagocytosis $=\frac{\text { granulocyte-associated } \mathrm{cpm}}{\text { total } \mathrm{cpm}}$

Killing of bacteria Granulocytes $\left(5 \times 10^{5}\right)$ and Staph aureus $\left(5 \times 10^{6}\right)$ in $0.5 \mathrm{ml} \mathrm{HBSS}+10 \%$ AB serum were incubated for $20 \mathrm{~min}$ at $37^{\circ} \mathrm{C}$. The number of bacteria remaining viable was determined by colony counting. From comparison with a control containing Staph aureus alone the percentage of the total bacteria killed could be calculated. Then:

$$
\begin{aligned}
& \% \text { granulocyte-associated } \\
& \text { Staph aureus killed }
\end{aligned}=\frac{\% \text { phagocytosis }}{\% \text { total bacteria killed }} \times \frac{}{\times 100}
$$

STATISTICAL ANALYSIS

Data were analysed using Student's $t$ test for matched pairs.

\section{Results}

During the period of the study the yields of white cells for the two methods were as follows:

Filtration leucapheresis $(n=136)$ : total WBC mean, $1.6 \times 10^{10}(\mathrm{SD} 0.55$; range $0.5-3.3)$; mean $\%$ granulocytes, 94 (SD 4.4; range 71-100) Haemonetics model $30(n=88)$ : total WBC mean, $1.2 \times 10^{10}$ (SD 0.36; range $0 \cdot 4-2 \cdot 1$ ); mean $\%$ granulocytes, 65(SD 15.5; range 23-93).

\section{GRANULOCYTE CANDIDACIDAL FUNCTION}

No significant difference was observed in ability to phagocytose and kill $C$ guilliermondii when either FL- or DFC-granulocytes were compared with preleucapheresis FI-granulocytes from the same donor. The results are shown in Table 1. For granulocytes 
Table 1 Candidacidal function of granulocytes harvested by filtration (FL) and discontinuous flow centrifugation (DFC) leucapheresis

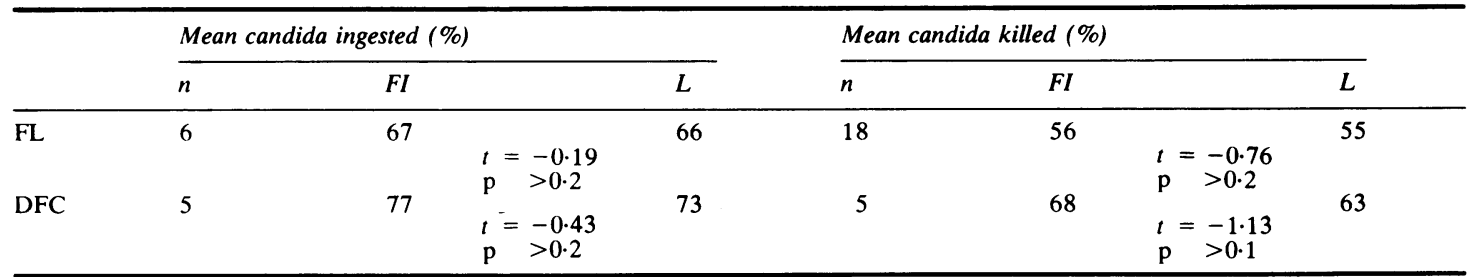

$\mathrm{n}=$ number of donors.

FI = Ficull-Isopaque separated granulocytes prior to donation.

$\mathbf{L}=$ granulocytes harvested by leucapheresis (FL or DFC).

Statistical analysis by Student's $t$ test for matched pairs.

Table 2 Bactericidal function of granulocytes harvested by fitration leucapheresis (FL)

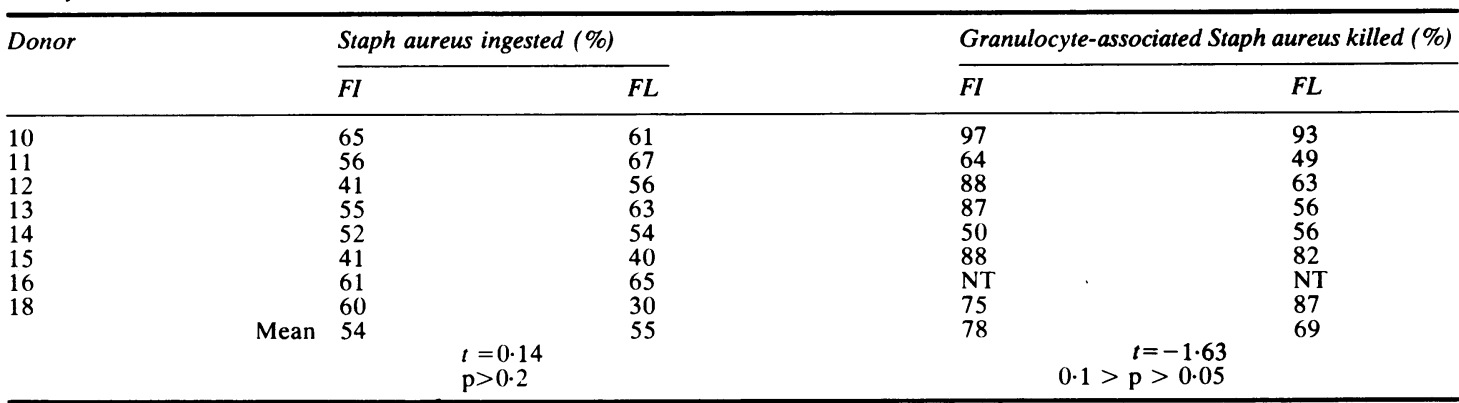

FI = Ficoll-Isopaque separated granulocytes prior to donation.

$\mathrm{FL}=$ granulocytes harvested by filtration leucapheresis.

NT $=$ not tested

Statistical analysis by Student's $t$ test for matched pairs.

Table 3 Bactericidal function of granulocytes harvested by discontinuous flow centrifugation leucapheresis (DFC)

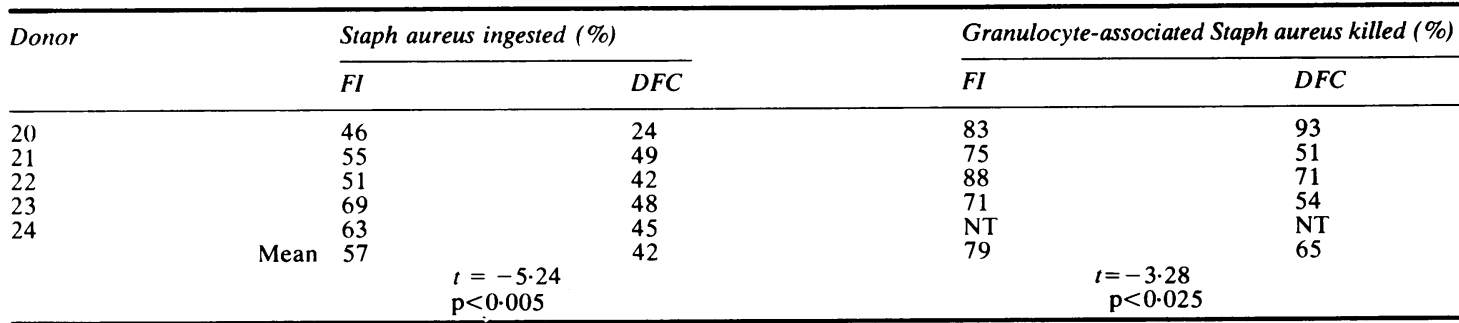

$\mathrm{FI}=$ Ficoll-Isopaque separated granulocytes prior to donation.

$\mathrm{FL}=$ granulocytes harvested using Haemonetics Model 30.

NT $=$ not tested.

Statistical analysis by Student's $t$ test for matched pairs.

harvested by filtration leucapheresis: mean \% candida ingested, $\mathrm{FL}=67 \% \mathrm{FI}=66 \%$; mean $\%$ candida killed, $\mathrm{FL}=56 \% \mathrm{FI}=55 \%$. For granulocytes harvested using the Haemonetics Model 30: mean $\%$ candida ingested, $\mathrm{DFC}=77 \% \mathrm{FI}=73 \%$; mean $\%$ candida killed, DFC $=68 \%$ FI $=63 \%$.
GRANULOCYTE BACTERICIDAL FUNCTION For granulocytes harvested by filtration leucapheresis the ability to ingest Staph aureus did not differ significantly from that of corresponding control FI-granulocytes: mean \% Staph aureus ingested, $\mathrm{FL}=55 \% \mathrm{FI}=54 \%$ (Table 2$)$. 
The percentage of granulocyte-associated Staph aureus killed was less for FL-granulocytes (69\%) than for control FI-granulocytes $(78 \%)$ but this difference was not significant at the $5 \%$ level (Table 2).

For granulocytes harvested using the Haemonetics Model 30 the ability both to ingest and kill Staph aureus was significantly reduced when compared with control FI-granulocytes: mean \% Staph aureus ingested: $\mathrm{DFC}=42 \% \mathrm{FI}=57 \%$; mean $\%$ granulocyte-associated Staph aureus killed, DFC = $65 \%$ FI $=79 \%$ (Table 3$)$.

\section{Discussion}

In this study the in vitro candidacidal function of granulocytes harvested by both FL and by DFC was normal. FL-granulocytes also showed a normal ability to ingest and kill Staph aureus. In contrast DFCgranulocytes showed a significantly reduced capacity to phagocytose and kill Staph aureus when compared with pre-leucapheresis granulocytes.

Although the function of granulocytes collected by continuous or discontinuous-flow centrifugation has generally been found normal, ${ }^{2-5}$ there has been a report of reduced morphological and functional integrity in DFC-granulocytes. ${ }^{10}$ The results of this present study provide further evidence that the function of granulocytes harvested using DFC may be functionally impaired, possibly as a result of degranulation induced during centrifugation. ${ }^{10}$ However, it should be stressed that while the bactericidal function of DFC-granulocytes was significantly less than that of FI-granulocytes, all results were within our accepted normal range.

Granulocytes collected by FL have generally been reported as showing morphological and functional abnormalities ${ }^{1-4}$ although some studies have found the cells to be normal. ${ }^{56}$ We have also found the function of FL-granulocytes to be normal. The discrepancies in the findings from different laboratories emphasise the importance of establishing a standard technique of collection. The reasons behind these differences may lie in the type of perfusion pump used, the rate of filter perfusion, the volume of blood perfused, the collection time, the type of eluting solution, the mechanism of elution and the solution in which the granulocytes are finally resuspended. There is evidence to suggest that the shorter the time of contact between granulocytes and nylon fibres, the greater the integrity of the harvested cells. ${ }^{25789}$ It has also been shown that vigorous manual tapping during elution of the filters has a markedly adverse effect on granulocyte function. ${ }^{48}$ When granulocytes are eluted with vigorous tapping this can cause $\mathrm{H}_{2} \mathrm{O}_{2}$ release from resting cells, probably as a result of perturbation of the plasma mem- brane. ${ }^{16}$ It is difficult to standardise the extent to which filters are tapped and this could explain much of the variation in results between laboratories and even between technicians within one laboratory. It is our practice to tap the filters gently during the elution procedure but Stegmann et $a^{8}$ have proposed the development of a mechanical gentle-tapping system to minimise damage to granulocytes. Another important consideration is the final centrifugation to concentrate the granulocytes for transfusion. Centrifugation speeds have varied from $80 \mathrm{~g}$ to 2800 $g .{ }^{3516}$ Centrifugation at a low $g$-force minimises damage to granulocytes. In order to optimise the harvesting conditions for FL-granulocytes we would suggest a collection time of less than two hours, gentle tapping of the filters used during elution with buffer at $\mathrm{pH} 6.5$, concentration of granulocytes at $400 \mathrm{~g}$ and resuspension in FFP.

Although the clinical gain from granulocyte transfusions is difficult to evaluate it has been shown that filter-collected granulocytes can function normally in the recipient ${ }^{617}$ and Aisner et $\mathrm{ll}^{17}$ have shown the clinical efficacy of FL-granulocytes to be superior to that of DFC-granulocytes.

There is evidence that granulocyte transfusions can favourably influence the outcome of lifethreatening infections in patients with severe neutropenia $;^{18}$ the value of prophylactic transfusions remains controversial. ${ }^{2021}$ It is apparent that because techniques for harvesting granulocytes differ, and, therefore, the functional integrity of these cells may vary from laboratory to laboratory, comparison as to clinical efficacy should be made with caution.

We are grateful to Professor DH Watson (Dept Microbiology, University of Leeds) and $\mathrm{Mr} \mathrm{KE}$ Major for their co-operation. This study was supported by a grant from the Special Trustees, Leeds General Infirmary.

\section{References}

${ }^{1}$ Wright DG, Kauffman JC, Chusid MJ, Herzig GP, Gallin JI. Functional abnormalities of human neutrophils collected by continuous flow filtration leukapheresis. Blood 1975;46:901-11.

${ }^{2}$ McCullough J, Weiblen BJ, Deinard AR, Boen J, Fortuny IE, Quie PG. In vitro function and post-transfusion survival of granulocytes collected by continuous flow centrifugation and by filtration leukapheresis. Blood 1976;48:315-26.

${ }^{3}$ Wade PH, Skrabut EM, Vincignerra L, Valeri CR. In vitro function of granulocytes isolated from blood of normal volunteers using continuous flow centrifugation in the IBM-Aminco Centrifuge and adhesion filtration leukapheresis using nylon fiber. Transfusion 1977;17:136-40.

4 Feliu E, Woessner S, Matutes E, et al. Comparative morphology of granulocytes collected by three methods of leukapheresis. Transfusion 1981;21:517-26.

${ }^{5}$ Steigbigel RT, Baum J, MacPherson JL, Nusbacher J. Granulo- 
cyte bactericidal capacity and chemotaxis as aftected by continuous flow centrifugation and filtration leukapheresis, steroid administration and storage. Blood 1978;52:197-209.

- Arnold R, Pfleiger H, Wiesneth M, Bhaduri S, Bültmann B, Heimpel $\mathrm{H}$. In vitro and in vivo studies on filter collected granulocytes. Scand J Haematol 1981;26:31-6.

' Iacone A, D' Antonio D, Di Bartolomeo P, Di Girolamo G, Fioritoni G, Torlontano G. Improved collection of granulocytes by modified continuous flow filtration leukapheresis techniques. Haematologica 1980;65:755-68.

${ }^{8}$ Stegmann G, Mishler JM, Maffete HL, Berberg H. In vitro granulocyte function as affected by filter loading time and tapping during filtration leukapheresis. Vox Sang 1980; 30:191-6.

${ }^{9}$ Moser R, Meuret G, Senn HJ. Funktionelle Veranderungen der Neutrophilen und Monozyten durch Konditionierung und Filtrations-Leukapherese? Blut 1980;41:347-57.

${ }^{10}$ Beaud M, Schooneman F, Girot M, Vigneron C. Qualités fonctionnelles des polynucleaires séparés par cytapherese sur Haemonetics 30. Pathol Biol (Paris) 1981;29:89-93.

"Boyum A, Separation of leucocytes from blood and bone marrow. Scand J Clin Lab Invest 1968;21: (suppl 97): 1-109.

12 Yamamura M, Boler J, Valdimarsson H. Phagogcytosis measured as inhibition of uridine uptake by Candida albicans. $J$ Immunol Methods 1977;14:19-24.

${ }^{13}$ Solberg CO. Influence of phenylbutazone on the phagocytic and bactericidal activities of neutrophils granulocytes. Acta Pathol Microbiol Scand [B] 1974;82:258-62.

${ }^{14}$ Martin S, Ghoneim ATM, Child JA. A new neutrophil candida killing test: ${ }^{51}$ chromium release from Candida guilliermondii.
J Clin Pathol 1980;33:757-61.

15 Verhoef J, Peterson PK, Quie PG. Kinetics of staphylococcal opsonization, attachment, ingestion and killing by human. polymorphonuclear leukocytes: a quantitative assay using $\vec{F}$ ${ }^{3} \mathrm{H}$-thymidine labelled bacteria. J Immunol Methods 1977; 14:303-11.

${ }^{10}$ Suzuki H, Kakinuma K, Shimizu M, Sakamoto H, Shimade K. $\mathrm{H}_{2} \mathrm{O}_{2}$ release from filtration leukapheresis-procured leukocytes. Vox Sang 1980;39:256-63.

${ }^{17}$ Aisner J, Schiffer CA, Wiernik PH. Granulocyte transfusions: evaluation of factors influencing results and a comparison of filtration and intermittent centrifugation leukapheresis. $\mathrm{Br} \mathrm{J}$ Haematol 1978;38:121-9.

${ }^{18}$ Graw RG, Stout FG, Herzig RH, Herzig GP. Granulocyte transfusion therapy for life-threatening bacteraemia. Prog Clin $\vec{\omega}$ Lab Res 1977;13:267-80.

19 Herzig RH, Herzig GP, Graw RG, Bull M, Ray KK. Successful granulocyte transfusion therapy for Gram negative sep-? ticaemia. $N$ Engl J Med 1977;296:701-5.

${ }^{20}$ Higby DJ. Editorial Granulocyte transfusions: where now? $N$ o Engl J Med 1981;305:636-8.

2 Strauss RG, Connett JE, Gale RP, et al. A controlled trial of $\mathscr{O}$ prophylactic granulocyte transfusions during initial induction chemotherapy for acute myelogenous leukaemia. $N$ Engl $J$ 윽 Med 1981;305:597-603.

Requests for reprints to: Dr JA Child, Department of $<$ Haematology, The General Infirmary at Leeds, Great $\vec{\bullet}$ George Street, Leeds LS1 3EX, England. 